\title{
Border and Memory in the village of Koshovice
}

\author{
Nicos Koutsourakis \\ Panteion University of Social and Political Sciences \\ Stefania Vasilaki \\ Vrije Universiteit Amsterdam \\ Maritina Vlachaki \\ Panteion University of Social and Political Sciences
}

\begin{abstract}
This article focuses on the village of Koshovice, Albania, where its residents are part of the officially recognized Greek minority. The local perceptions of the community are discussed as linked to the Albanian-Greek border and its presence in the collective memory. After the borderline creation in 1913, local residents were divided between the two neighboring countries. The ethnographic data collected underline the experiences and the everyday practices of the villagers of Koshovice, especially during the period of the Albanian socialist state between 1945 and 1991, when the border became almost impenetrable. The article then discusses the changes after the fall of socialism and the opening of the border in the early 1990s, especially showing how the local borderland communities are still connected nowadays to each other despite the inter-state division.
\end{abstract}

Key-words: Borderscape, Minority, Community, Collective memory, Southeastern Europe.

The village of Koshovice is located on the Albanian side of the borderline between Albania and Greece. This village belongs to the area of Dropull (Deropolis), which is a municipality and a predominantly Greek-inhabited region of the Gjirokastër County, located in southern Albania. The region's villages are part of the Greek 'minority zone' and are officially recognized by the Albanian government. In 1913 Albania became an independent state and the borders were created between Albania and Greece. Thus the local community of Koshovice was divided between the two states. Nowadays, there are two independent settlements: Koshovice on the Albanian side, and Aghia Marina on the Greek side. Until 1944, the communication between the two villages was open and thus, the borderscape had no security surveillance. During that period of time people regularly crossed the border mostly for working reasons and this mobility was a typical feature of the local population regardless of the different ethnic, religious, and linguistic identities (de Rapper 2004, 6). 
When World War II ended, Albania was transformed into a socialist state under Enver Hoxha's government, and the national border between the two countries closed. As a result, the local communities that had developed several relationships such as economic trades, cultural events and bonds of kinship between the residents of the two villages, became separated and isolated (Nitsiakos and Mantzos, 2008, 257). Furthermore, the socialist government inflicted strict restrictions on the movement of people, both abroad and within the country. In that way, the authorities imposed the immobility of the population as one of the state's principles (Gregorič Bon 2017, 303). Under this premise, the communication between the two villages evolved to be stricter and more limited than before.

This article focuses on the concept of the border and its social consequences through the prism of Koshovice. To this end, we discuss how the people of Koshovice interpret the meaning of the border. ${ }^{2}$ This research aims to explore two points: first, how the locals have challenged the strictness of the border through everyday practices, and second, how the border presence has affected the divided communities throughout the years. These two aspects will be evaluated within the analytical frame of the collective memory of the community.

\section{Koshovice}

Our ethnographic field site lies about 500 meters away from the borderline. As mentioned above, the demarcation of the border between Albania and Greece in 1913 split the village in half and cut it off from most of the agricultural and livestock areas, which in turn became part of the Greek territory. According to Voula, one of our interlocutors who lives and works in Athens, Koshovice and Aghia Marina were considered as two neighborhoods belonging to the same village. ${ }^{3}$ The area of Aghia Marina, formerly called Vatsounia, was a natural continuation of the main settlement and included the arable land of the village. Gradually, an independent settlement in the Vatsounia region was created by Koshovice's residents who chose to settle permanently in Greece and keep contact with their relatives that were living on the other side of the border. Meanwhile, with the passage of time this new settlement was renamed by the Greek authorities to Aghia Marina. According to Takis, a 40-year-old resident of Koshovice, the specificity of this new settlement reflects the allocation of the houses that are quite far from each other: 'Koshovice was the center of the village. In Aghia Marina, there were only sheepfolds and agricultural fields. Over the years, villagers from Koshovice settled permanently in Aghia Marina and built their homes where their fields used to be. For this reason, the houses are far from each other.'

This arrangement was overthrown with the establishment of the Albanian socialist state in 1944. During this period the supervision of the Greek-Albanian borderline intensified, and the military was guarding the border on both sides. As Maria, a 60-year-old woman who lives in Koshovice and Athens told us: 'After World War II, the border was guarded by the army, while barbed wire was placed on the paths that connected the two settlements.' Thus, during the socialist period most of the villagers continued to work as land workers, but the agricultural production and the arable land in the Albanian side was controlled by the local state-owned agricultural cooperative. 
According to the collected interviews, the majority of the village infrastructure collapsed after the fall of the socialist state in the early 1990s. The agricultural cooperative was disbanded, while the community's school and the cooperative's stores ceased to operate. Furthermore, most of the village's population migrated to Greece due to the reopening of the border. Today, Koshovice is a small and isolated village. The road that connects the village with the main highway is poorly maintained and the bridge that was located at the entrance of the village has collapsed, making the road very dangerous for vehicles. In Koshovice there are a few residents during the winter, most of whom are elders. In the summer, the village population increases due to the return of the villagers who have migrated abroad, for their summer vacations.

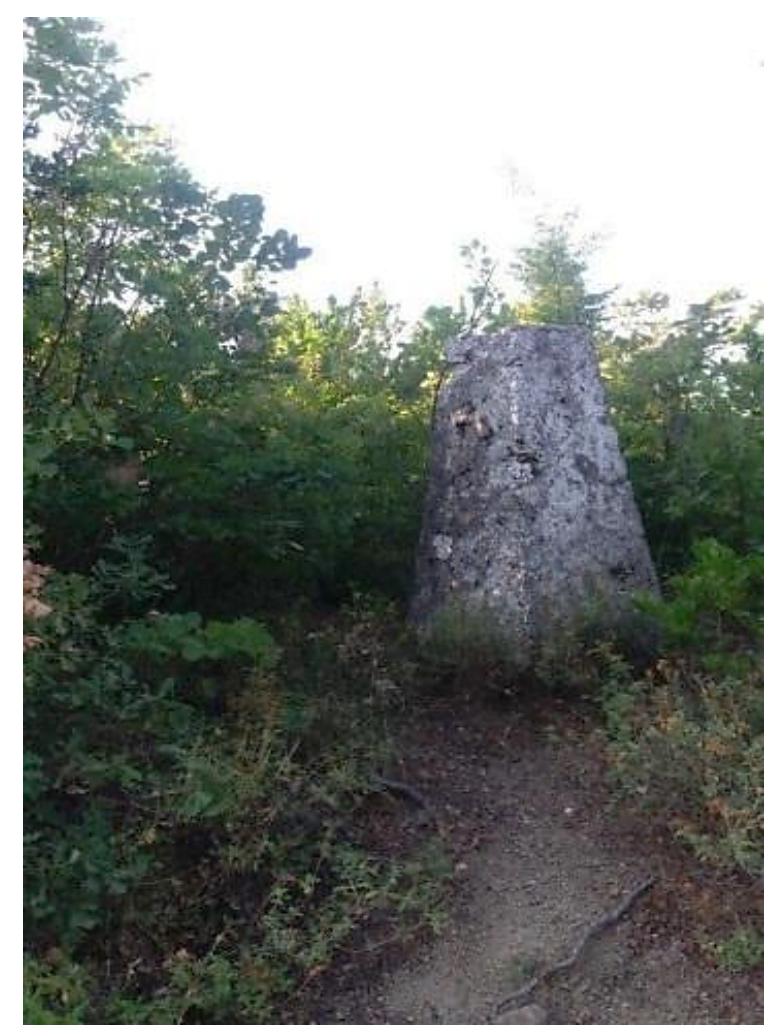

Photo No. 1 - The stone that defines the borderline between Greece and Albania is located 500 meters from the village. ${ }^{4}$

\section{Border and the collective memory of the community}

The concept of the border is a key point of our research, and provides the basis for this article. Anthropologist Sarah Green $(2018,67)$ argues that the concept of borders, as straight lines on the map, is a result of specific political and historical perceptions, which ignore the complex reality that exists in border areas. For many theorists, borders represent powerful political spaces in which there are possible cracks in homogenizing discourses based on ethnicity, gender, race, and sexuality. Therefore, they conclude that borders are counters that 
have the ability to consolidate power or to challenge it through the existence of hybrids and crosses (Cunningham and Heyman 2004, 291). Following the approach of Donnan and Wilson (2010), we conclude that it is not possible to exclude the political context of the meaning of the border or to assume that its dimensions are shaped in a passive way. Although such dimensions are actively shaped and often visible, there are always some implicit and invisible aspects that underline the concept of the border. For those who live in the borderlands, it is a common practice to assume the border as something invisible (Donnan and Wilson 2010, 5). Borders can also be understood as 'gates', temporarily and selectively open or closed. Despite the main condition of its penetrability, populations from the two sides of the border are often related and manage to communicate with each other. For this reason, an anthropological analysis of borders and borderland areas must consider people and institutions from different ethnic groups and nations while also take into account actions that lead to border managing decisions either by the state or by the local residents. In the end, it is important to remember that people living on the borders are often agents in the construction, negotiation and maintenance of the border, and thus influence social, financial, and political changes, beyond their locality and sometimes beyond their state.

Collective memory is the second term we employ for our analytic frame. This research focuses on how the local community remembers its past, especially the separation period. The term collective memory was introduced by the French philosopher and sociologist Maurice Halbwachs (1992), who argues that individual memory is a part or even an aspect of collective memory. In this view "memory is not just about the person, but about the community and the collective as well" (Abrams 2010,114). At the same time, it is evident that memory does not remain unchanged throughout the years, but it is a "dynamic process of reconstruction, through which the traces of the past interrelate, to tell a story" (Abrams 2010,114). For Marie-Claire Lavabre memory is a "space of communication" (Todorova 2014, 7), while Szacka (Main 2014, 98-99) considers that collective memory is a representation of a collective past, which is built on individual and personal memories. These personal memories are transformed within the framework of the common cultural perceptions shared by a community.

Community "is symbolically constructed as a system of values, norms, and moral codes, which provides a sense of identity within a bounded whole to its members" (Cohen 2001, 9). The community of Koshovice is geographically well defined because the people consist in a small social group located at Koshovice who, as Keesing puts it, "recurrently interact in an interconnected set of roles" (Amit and Rapport 2002, 14). However, at the same time its members also belong to the imagined community of the Greek nation, which "is imagined because the members will never know most of the fellow members, yet in the mind of each, lives the image of their communion" (Anderson 1983, 6).

Identity "can only be understood as a process of 'being' or 'becoming'" (Jenkins 2008, 17). It is not fixed, immutable, or primordial, rather utterly sociocultural in its origins, negotiable, and flexible (Jenkins 2008), while it is produced through the "interaction between relationships of similarity and difference" (Jenkins 2008, 200). It is also important to mention that "collective identity" - the one that we are discussing in this article - "is as much an interactional product of 'external' identification by others as of 'internal' self-identification" (Jenkins 2008, 200). 


\section{Historical frame}

Albania was recognized as an independent state in 1913, after the London Conference that took place in the same year. Before this period, Albania was part of the Ottoman Empire, and ethnic Albanians or other ethnic groups such as Vlachs, Macedonians, Armenians, and Greeks resided within this area. However, the Greek minority was the most compact ethnic group in political terms (Pettifer 2001, 2). The Greek minority lived mainly in the south of the country, and the Greeks call this region 'Northern Epirus'. This region was the locus of discord in the early 20th century. The Greek state was able to gain independence from the Ottoman Empire after the First Balkan War of 1912-1913 and incorporated a substantial part of the region called 'Epirus', but not the entire area (Baltsiotis 2010, 2).

Although the Greek forces failed to integrate all parts of the Epirus area, Greek irredentists occupied the city of Gjirokastër and its surrounding areas, proclaiming these lands as part of Greek territory. In 1914, after some clashes between the Albanian forces and the separatists, a provisional government was established in Gjirokastër, which declared the region of Southern Albania as autonomous under the name of Autonomous Republic of Northern Epirus (Baltsiotis 2003, 53).

The outbreak of World War I and the political situation in Greece made the Greek government unable to support the newly established autonomous Republic and thus, it was later overthrown. The whole area was returned to Albanian territory in 1925 and the newly formed borders were based on the same borders as were set in 1913 (Pettifer 2001, 5). The Greeks of the area were naturalized as Albanian citizens, but at the same time they were officially recognized as members of the Greek minority by the Albanian state. During that period, the term 'Northern Epirus' was used by Greek nationalists to describe the areas Greece had failed to prevail upon. This term was heavily politicized and invested with irredentist meanings. In the consciousness of the lower Greek social classes, the region of Northern Epirus had transformed into an 'enslaved sister' and the term 'Northern Epirotes' signified a separate part of the Greek population living in Albania (Nitsiakos, 2013, 245).

In 1944, the partisan movement managed to liberate Albania from the occupation forces of the Axis and established a socialist republic under the strict rule of Enver Hoxha. The socialist regime was of benefit for this ethnic minority for two reasons: Firstly, because of the residents' attitude during the war in the minority zone, who sided with the guerrilla movement against the occupation forces, and second because the Greek minority was the regime's alibi regarding the respect for human rights ${ }^{5}$ at the international level (Baltsiotis 2010, 4). However, the socialist government was suspicious of the Greek minority, and under its overall rhetoric of respect for minority rights, existed the desire for the subordination of the minority to the regime (Nitsiakos 2013, 247).

The conditions for the minority in southern Albania changed radically, once again, in the 1990s. In December 1990, the socialist state collapsed, and in March 1991, the first free elections were held. Because of intense financial problems, the political situation of the country remained unstable throughout the decade. As a result, the change in political power led, to the 
revival of bilateral relations between Albania and Greece at the intra-state level. This was accompanied by the massive inflow of economic migrants from Albania to Greece, leading to the rising of nationalism in both countries (Valden 2019, 21). During the first years of the transition, nationalist sentiments were observed within the minority and were supported by political and religious circles in Greece.

In regard to the relationship between the minority and the border, the fall of socialism in Albania sparked waves of excitement. The boundary that separated for 50 years the two communities was now open. According to anthropologist Sarah Green (2010, 309), this enthusiasm reveals the belief that socialism was a parenthesis in the history of the area and now that the system has collapsed, things could return to their previous state. But this belief obscures the fact that the national borders were already established 30 years before socialism.

An important factor that shaped the history of the minority in post-socialist years is the experience of mass migration to Greece and the depopulation of villages. The migratory tendencies of these communities were a familiar strategy even before the socialist period. However, this phenomenon mainly focused on the male population and was temporary, without affecting the social balance of the community. Instead, after 1991, migration came to concern the whole population, especially the productive age, regardless of any gender criteria.

\section{The collective memory of Koshovice's residents about the border}

In this section, we explore a different angle regarding the meaning of the border, the collective memory, and the everyday life in the village of Koshovice. Such concepts will be discussed from the spectrum of before and after the collapse of the socialist state. Firstly, we will take a look at how people who live on the border formulate their memories regarding this subject, during the socialist period and in which ways the border's definitive closure has affected the local communities. Secondly, we will explore the attempts of the Greek minority to renegotiate their Greek identity after the opening of the border.

Our research data reveal that until 1991, the memory of the border, according to the residents of the community, was intertwined with the separation of the two communities. After 1991 the local population's concerns were focused on the social phenomenon of migration and especially on the migration of the Greek minority to Greece. Through the conducted interviews, it was highlighted that the residents of Koshovice kept in their memory only the definitive closure of the border in 1945 instead of the establishment of the borderline in 1913. For the residents of Koshovice, the definite closure of the border symbolizes their exclusion from the Greek state, which they recognize as their homeland. Therefore, such an action also refers to their separation from their Greek identity.

During the socialist era, the Albanian state was trying to incorporate the Greek minority into the central state. This phenomenon occurred through continuous controlling and surveillance strategies, especially in the Greek communities located near the border, like Koshovice. As a result, the residents affiliated the values and habits which were enforced to 
them under the actions of Hoxha government. Further, the collective memory of the residents about the border is formed in a variety of ways through everyday practices. The supervision of daily agricultural work is one such example. Due to the geographical location of the state fields, the farmers worked under the strict supervision of border guards, and they were obliged to show their identities in order to enter and leave the workplace. As a woman from Koshovice, Voula narrates:

One day, there was a boy in Kastaniani who yelled 'grandma-grandma it's me, Kostakis!' but the soldiers did not allow us to answer, not even to raise our heads because we were going to work in the fields, where they were located just before the neutral zone on the fence. There, there was a door that the soldiers were opening every morning for us. We had to show them our identities, and they were counting how many people were there. When we were finishing our work at night, we had to show them our identities again. We didn't have the right to leave the working field; we had very specific working places.

The collective memory concerning the permeability of the border was another important issue that has to be taken into account. The border of Albania opened officially in 1991, however, the border was already permeable since 1989. One interlocutor confirmed the fact that some residents from Koshovice (including her) started crossing the border secretly, by paying off the border guards. This secret crossing was conducted in order to visit their relatives in Aghia Marina from which they had been separated for the last 50 years. She also told us about an event where many residents from the Greek minority who lived near the border one day tried to cut down the fence that separates their communities from the villages in Greece. This action manifested as a symbolic gesture to express their intention to acquire their Greek identity.

After the opening of the borders in 1991, many residents from the communities near the border made a number of symbolic gestures that indicated their desire to affirm their Greek identity. For instance, in a short period of time, they established the institution of the Greek Orthodox Church in the area. The symbolic aspect of such an action is not only considered because the religious practices were banned during the previous system, but also because the Christian Orthodox religion is integral to the Greek identity (Nitsiakos, 2010). Owing to this, the local women from the area organized massive christenings for many children of the Greek minority. The interviews conducted reveal that, for the residents of Koshovice, their relatives who live in Aghia Marina play a significant part in their lives nowadays. According to their point of view, this role is established not only because they had not seen each other for 50 years, but also because the relatives from the Greek part are the living proof that the residents of Koshovice (and the other communities of the Greek minority) have Greek identity. In this sense, such relatives represented their connection with the Greek state.

According to the previous work of Van Boeschoten (2003), in the course of the socialist state, the collective memory of the residents was related to the fact that the border was closed 
and impermeable. As a result, the residents were not able to meet up with their relatives from the Greek side. When the border opened in 1991, another issue influenced the collective memory of the village of Koshovice: the phenomenon of migration to Greece. Although the work of Van Boeschoten (2003) does not refer to Koshovice, her assumptions apply to this case. According to Nitsiakos (2010), migration was a common practice in Albania not only after, but also before the opening of the border, although before the border opening only the male members of the community would migrate. Therefore, the local community kept having social cohesion and productivity as the migrants provided financial support to their families who left behind.

After the opening of the borders and the fall of socialism, many infrastructures collapsed, and most of the cooperatives closed. Hence, many residents from Koshovice were forced to migrate. During this period, both men and women participated in such migratory practices. At this point, many communities from the Greek minority - including Koshovice - became depopulated. It is also important to take into account that the remittances which were sent by the migrants to their relatives, who remained in Albania, were very valuable. However, the financial problem was irreversible because the entire productive workforce migrated from the community. As Nitsiakos (2010) mentions, owing to this workforce migration, after 1991 the community's cultivations were unseeded. As a result, the land could not be assigned utility value anymore, and its signification changed. More specifically, land possession was then related to the property acquisition and to 'rooting in place'. Owing to this situation, many residents of the Greek minority started feeling nostalgic about the previous order. In their narrations during our research, we observed that local people did not keep in their memory the previous political situation, but they kept the fact that under socialism there was a sense of unity and productivity in the community, as previous work also elaborates (Kasimis and Nitsiakos 1996, 131).

Another prominent part of the collective memory was the migration, as it was perceived by the residents of Koshovice who migrated to Greece after 1991. Following the opening of the borders, the Greek minority was in a liminal condition because they were accepted neither by the Greek state nor by the new Albanian state. Under this premise, the aforementioned facts can be verified both from our fieldwork and from the previous work of Nitsiakos (2010). While they were considered as Greeks by the Albanians, the Greeks addressed them as Albanians. According to the collected interviews, we noticed that it was notably important for the Greek minority to take Greek citizenship and to be identified as members of the Greek minority.

Through the obtained research data we conclude that this was a bureaucratic process that required many years. When they migrated to Greece, the majority of them became workers undertaking precarious forms of labor, and they were called 'Northern Epirotes'. This political naming assigns a negative meaning which also reflects on another issue of collective memory, concerning the difficulty of integration - as residents of the Greek minority from Albania - in the Greek society. 


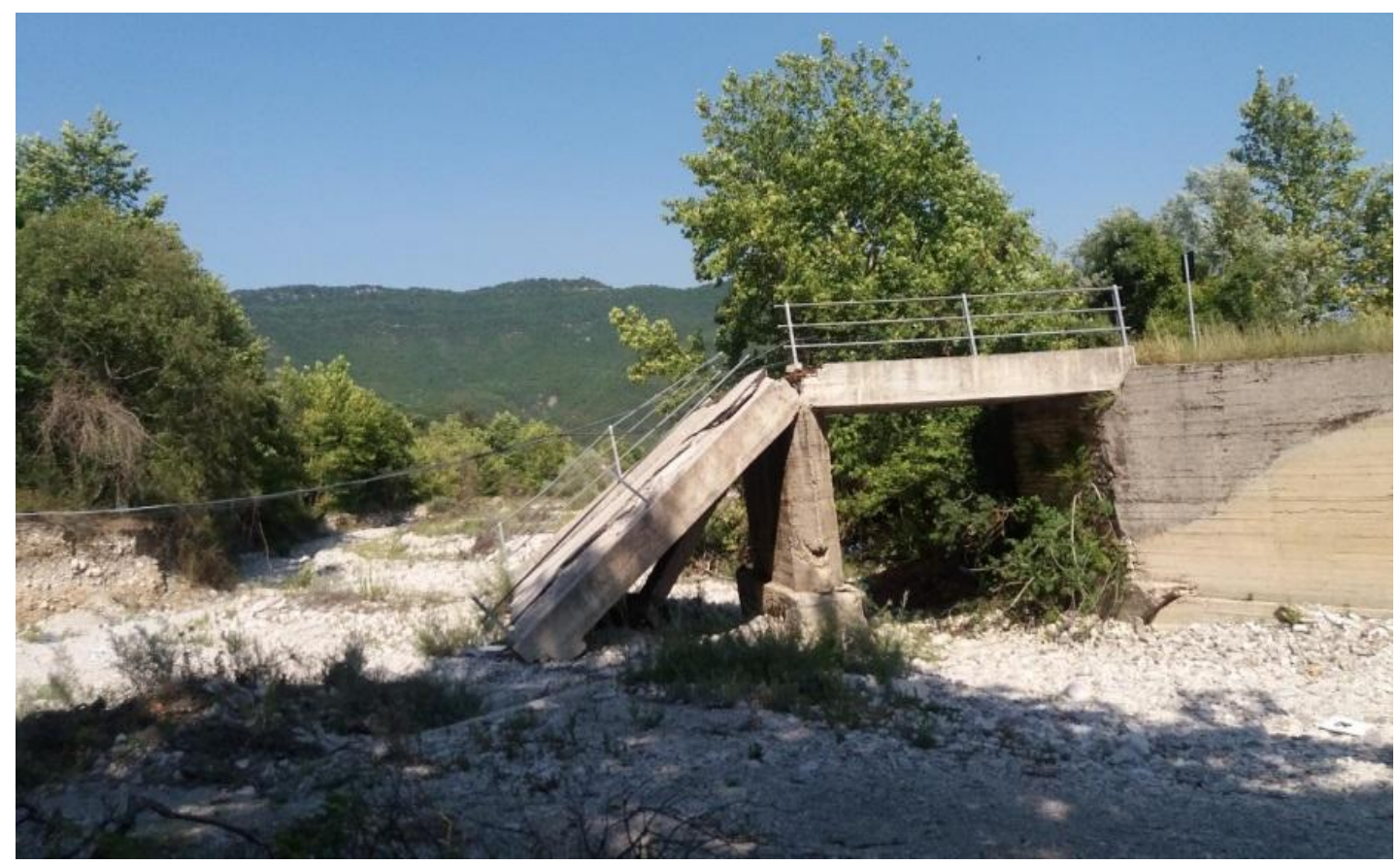

Photo No. 2 - The collapsed bridge that is located outside of the village.

\section{The relations between Koshovice and Aghia Marina throughout the years}

It is clear that the relations between these two communities across the border are influenced by the ever-changing nature of that border. As Nitsiakos (2010) has shown, the border can be considered a geographical entity, but a pure geographical perception would be insufficient regarding its symbolic aspect emerges, and the identities of the local residents. Liminal groups can be geographically marginal, but often their symbolic role is pivotal. That happens because the boundaries are usually a place where unity with the 'same' set is found. Additionally, the inhabitants of Koshovice and Aghia Marina are connected with bonds of kinship, which is crucial to their relations throughout the years. Therefore, if we consider the historical changes of the region, the significance of the border and kinship in the perspectives of local people becomes more apparent.

Despite the official establishment of the border between Albania and Greece in 1913, the residents of Koshovice did not perceive it as a strict border, or at least not as strict as the one set by Hoxha. As Takis, a 40-year-old permanent resident of Koshovice, and his mother Maria, detail, 'the border was open. [...] There were paths, but in each one of them there was a gatehouse with guards. From there, you could receive an official document that testified that you were from Koshovice.' Using that, locals could cross the border to visit their lands in today's Aghia Marina, then Vatsounia. According to another informant Voula, 'Aghia Marina was the other half of the village. It was our village's fields; it was the huts where people held their sheep. And one day, the church bell was ringing, and people were asking who died. And then other people responded it was the village that died because they took it from us'. Vatsounia was growing, little by little. As a result, when the border was utterly closed in 1945, a fact no one could have predicted, Aghia Marina was already developed according to our interlocutors. 
As a result, many local families never saw their relatives in Koshovice for approximately 50 years.

This leads us to the question, 'what happened during Hoxha's time as leader of Albania and how did all these relatives lose contact or keep in touch across the border?' There were ways to communicate, not without struggles, but there were also cases in which communication was almost impossible. Regarding the first case, according to Takis and Maria, some people from Aghia Marina were writing letters to their relatives, which frequently arrived open in Koshovice or did not arrive at all. As Voula says, the same thing was happening with packages, from which things were sometimes missing. On the other hand, the case of Thodoris, a teacher whose mother was from Koshovice and whose father from Aghia Marina, is different. Before 1945, his father was working in Greece and often visited Albania for brief periods of time. After the establishment of the border, he returned to his job and the Albanian government considered him a fugitive. As a result, Thodoris could not communicate or see his father for 40 years. This changed in January 1985, with the opening of the customs in Kakavia. This first border opening was arranged between the two countries, in order for some selected locals to see their relatives. According to Voula:

Some people came from Greece and selected [...] those who had relatives in the village over there [Aghia Marina]. Maybe 20 - 15 people from all the villages of the area. They went there [Kakavia] to see their relatives, but the border remained in the middle. At first, they wouldn't open the fence, and the people could only see each other from a distance. Then, they realized they couldn't continue like this, so they opened the gates, and people started crying.

That is when Thodoris saw his father for the first time. Generally, around 1985, the state adopted a looser border control, and people from Koshovice could travel for the first time to Greece and meet their relatives in Aghia Marina. Nonetheless, this trip was not possible without specific state documentation, which of course was hard to obtain.

This was the reality for those who chose the legal way, but there were other options as well. Voula told us a story about her brother, Giorgos, crossing the border from Koshovice to Aghia Marina. There, he visited his aunt, who told him to return immediately. She knew that back in Albania if they realized that he had escaped, there would be severe consequences upon his family. Voula, as a pregnant woman, also crossed the border, following the path to Aghia Marina. It was December of 1989 when, with three other people, they bribed the guards and after a demanding walking route, they arrived in Aghia Marina. There she visited her aunt and her cousins and then she returned to Koshovice. We should note that the border crossing during this period of time was much easier compared with the era her brother decided to cross the borders.

Although the official opening of the border was in 1991, local residents started to challenge its premises long before that date by making numerous symbolic actions, such as the illegal border crossings or the slow but gradual ripping off the border fences, as Voula mentioned. Nevertheless, it was a specific symbolic action that signified the definite opening of the border. This re-signification occurred with the first grand festivity that included collective christenings. According to Voula, the festivity took place in Koshovice, after the 
collapse of the socialist state (around the summer of 1991) and it was organized by the Women of Epirus Association. Many villages, such as Llongo, Kastaniani, Sotira, and of course Aghia Marina, took part in this activity. The aim was to christen the minority's children and establish bonds of friendship between Koshovice and Aghia Marina. The Women of Epirus Association brought Orthodox priests from the villages of the Greek territory. They priest baptized around 70 kids, and the people celebrated this with food, dance, and polyphonic music. As Voula tells us: 'Now, we keep organizing fests and people from the other half of the village, which is Aghia Marina, are coming to our fests and we are visiting theirs. We celebrate together.'

Today, the relations between the two villages are very close, and kinship plays an important role to this. As we have heard from the people of Koshovice, they keep visiting their relatives in Aghia Marina, and also voted there for the last Greek elections ${ }^{6}$. According to Vlahaki, Tsintsirakos and Kokkinou "the politics of culture are practiced by members of the Greek minority in Albania in an effort to construct and represent a minority identity which manifests its national affiliation with the population on the Greek side of the border" (Manos 2016, 7). These people were cut off from their relatives and the Greek identity with the closing of the borders. Now, as they emphasize their kinship with the residents of the other half village in Greece, they approach once more their 'lost' Greek identity.

\section{Conclusion}

Since the opening of the border, the residents of Koshovice and Aghia Marina have coorganized religious festivities during the summer period. This atmosphere of cooperation belies what has been a complicated past, as we have discussed above, when the border arbitrarily separated ethnocultural groups who share similar social characteristics (Nitsiakos and Mantzos 2008, 255). However, this new air of cooperation is now being threatened by other forces. In recent years, many elderly residents of Koshovice have passed away. As a result, the community fears and mourns for the social death of the village and all the religious festivities have recently been cancelled, thus prolonging the feeling of desolation among villagers. Besides, in regions like Epirus, where the borders are contested, cultural identities can be considered notably dangerous for national cohesion (Green 2010, 300). Similarly, the identity of the 'Northern Epirotes' before the collapse of the socialist system was considered 'dangerous' for the Albanian state. On the other hand, after the opening of the borders and the following massive migration to Greece, the name 'Northern Epirotes' was assigned a negative meaning in Greece. As a result, 'Northern Epirotes' were considered a threat to the Greek national homogeneity.

As for the collective memory of such communities, we must take into account that local narratives about the past are influenced by the experiences of the present (Van Boeschoten 2003). Therefore, it stands to reason that collective memory is a dynamic procedure that can combine fragments from the past and the present, which means that it can construct a desirable future. That is why nostalgic feelings are clearly noticeable among the members of the community. In this sense, the desirable future for them is the revival of social life in the village of Koshovice. 
Regardless of the harsh conditions that were elaborated above, the people of Koshovice did not necessarily call for the complete dismantling of the community, and those who live abroad have found associations and organize traditional fests in Greece. As our interlocutors told us, the people of Koshovice in Greece manage to distribute their time between their current residence in Greece and the village, engaging themselves in the preservation of a sense of community. Many communication bridges with Koshovice have fallen down, but many others persist.

\section{Notes}

${ }^{1} \mathrm{We}$ would like to express our gratitude to the anthropologists from the Border Crossings Network, who organized the Konitsa Summer School and provided assistance to us during our first anthropological research. In particular, we want to share our appreciation for Professor Vassilis Nitsiakos. His companionship in the field and his expert guidance taught us valuable lessons on how to conduct anthropological research. We are also thankful to Aliki Angelidou and Zeliha Nilüfer Nahya. With their remarks, they supported us through this research, and encouraged us up to the final form of the essay. Finally, we are much obliged to our interlocutors, that shared with us their deepest thoughts and feelings with courtesy and hospitality.

${ }^{2}$ The team - consisting of three undergraduate students at that time - had the opportunity to visit the village of Koshovice during the short ethnographic research within the Konitsa Summer School, taking place from the 26 to the 30th of July in 2019. Our ethnographic data are based on unstructured interviews in Greek, on field notes, and on photographs. Furtherly, we had the chance to carry out a structured interview in Athens with a former resident of the village who lives and works in the Greek capital for the last 20 years.

${ }^{3}$ All the names of the interlocutors in the article are pseudonyms.

${ }^{4}$ All photographs in this article were taken by Maritina Vlachaki.

${ }^{5}$ In the context of minority rights, the teaching of the Greek language was introduced in the villages of the minority area but not in the cities where a Greek-speaking population was also located (Baltsiotis 2003, 47).

${ }^{6}$ The residents of Koshovice are officially recognized members of the Greek minority located in Albania and, for that reason, voting rights in Greek elections have been provided to them. The aforementioned information turned out during the interviews, and while such a premise is interesting, any further elaboration on this topic is outside of the scope of this work. 


\section{References}

Abrams, Lynn. 2010. Oral history theory. New York: Routledge.

Amit, Vered, and Nigel Rapport. 2002. The Trouble with Community: Anthropological Reflections on Movement, Identity, and Collectivity. London: Pluto Press.

Anderson, Benedict. 1983. Imagined Communities: Reflections on the Origin and Spread of Nationalism. London: Verso.

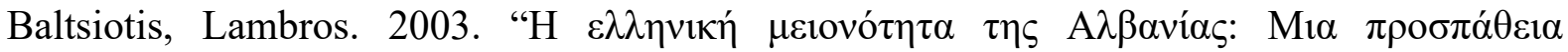

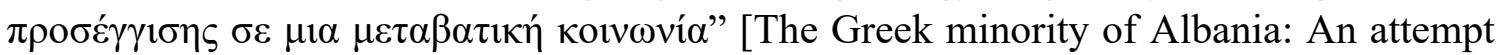

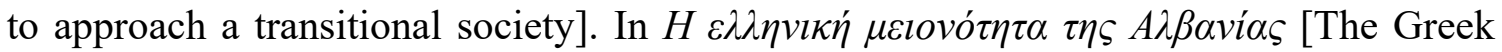
minority of Albania], edited by Konstantinos Tsitselikis and Dimitris Christopoulos, 45125. Athens: Kritiki.

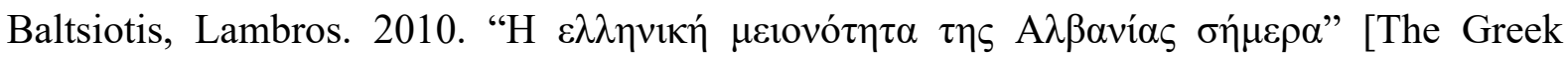

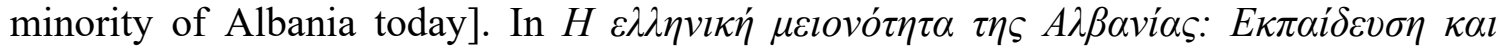

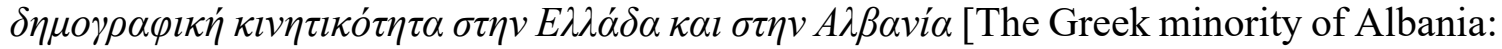
Education and demographic mobility in Greece and Albania], edited by Konstantinos Tsitselikis, Grigoris Tsioukas, Dimitris Christopoulos, Miltos Pavlou, and Lambros Baltsiotis, 2-24. Athens: Latsis Foundation.

Cohen, Anthony P. 2001. The Symbolic Construction of Community. London and New York: Routledge.

Cunningham, Hilary, and Josiah Heyman. 2004. "Introduction: Mobilities and Enclosures at Borders". Identities: Global Studies in Culture and Power 11, no. 3: 289-302.

de Rapper, Gilles. 2004. “'We are not Greek, but...': Dealing with the Greek-Albanian Border among the Albanian-speaking Christians of Southern Albania." Journal of Southeast European and Black Sea 4, no. 1: 162-174.

Donnan, Hastings, and Thomas M. Wilson. 2010. "Ethnography, Security and the 'Frontier Effect' in Borderlands." In Borderlands: Ethnographic Approaches to Security, Power, and Identity, edited by Hastings Donnan and Thomas M. Wilson, 1-20. Lanham: Rowman and Littlefield.

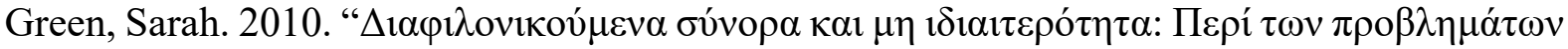

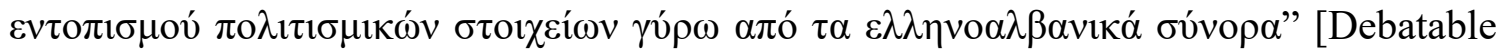
borders and non-particularity: Regarding the problems of detecting elements of culture

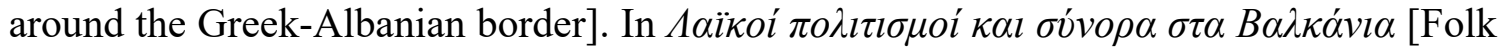
cultures and borders in the Balkans], edited by Euaggelos Audikos, 291-325. Athens: Pedio.

Green, Sarah. 2018. "Lines, Traces, and Tidemarks: Further Reflections on Forms of Border". In The Political Materialities of Borders: New Theoretical Directions, edited by Olga Demetriou and Rozita Dimova, 67-83. Manchester: University of Manchester Press.

Gregorič Bon, Nataša. 2017. "Movement Matters: The Case of Southern Albania." Ethnologie française 47, no. 2: 301-308.

Halbwachs, Maurice. 1992 [1925]. On Collective Memory, edited by Lewis A. Coser. Chicago: University of Chicago Press.

Jenkins, Richard. 2008. Social Identity. London: Routledge. 
Kasimis, Charalambos, and Vassilis Nitsiakos. 1996. "The Greek minority of Albania. Transition or Catastrophe?" In Les mécanismes de la transition dans I'Europe des transformations. Actes, 71-83. Athens: A.N. Sakkoulas.

Main, Izabella. 2014. "The Memory of Communism in Poland." In Remembering Communism. Private and Public Recollections of Lived Experiences in Southeast Europe, edited by Maria Todorova, Augusta Dimou, and Stefan Troebst, 97-117. Budapest: Central European UP.

Manos, Ioannis. 2016. "Understanding borders and border processes. The ethnographic study of international frontiers in Southeast Europe." In Ethnographic Research in Border Areas: Contributions to the Study of International Frontiers in Southeast Europe, edited by Ioannis Manos, Georgios Agelopoulos, Aliki Angelidou, Vassilis Dalkavoukis, Vasiliki Kravva, and Vassilis Nitsiakos, 4-13. Konitsa: Border Crossings Network Konitsa Summer School.

Nitsiakos, Vassilis. 2010. On the Border. Transborder Mobility, Ethnic Groups, and Boundaries Along the Albanian-Greek Frontier. Münster: LIT Verlag.

Nitsiakos, Vassilis. 2013. “ 'Brothers' becoming 'Others'. The Greeks of Albania in Greece after 1990." In Myths of the other in the Balkans: Representations, Social Practices, Performances, edited by Nikitas Palantzas and Fotini Tsibiridou, 245-250. Thessaloniki: Paris Aslanidis.

Nitsiakos, Vassilis, and Kostas Mantzos. 2008. "Migration and National Borders. Albanian migrants to Greece. A local case." In Balkan Border Crossings: First Annual of the Konitsa Summer School, edited by Vassilis Nitsiakos, Ioannis Manos, Georgios Agelopoulos, Aliki Angelidou, and Vassilis Dalkavoukis, 248-273. Münster: LIT Verlag. Pettifer, James. 2001. "The Greek Minority in Albania in the Aftermath of Communism." South Slav Journal 22, no. 3-4: 13-32.

Todorova, Maria. 2014. "Introduction. Similar Trajectories, Different Memories". In Remembering Communism. Private and Public Recollections of Lived Experiences in Southeast Europe, edited by Maria Todorova, Augusta Dimou and Stefan Troebst, 1-25. Budapest: Central European UP.

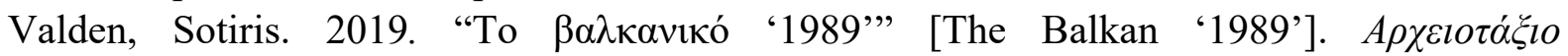
[Archeiotaxio] 21: 180.

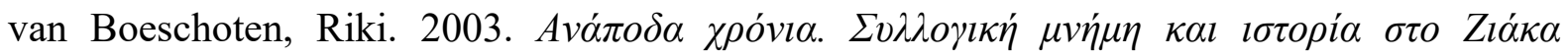
$\Gamma \rho \varepsilon \beta \varepsilon v \omega ́ v(1900-1950)$ [Inverted years: Collective memory and history in Ziakas Grevena (1900-1950)]. Athens: Plethron. 